\title{
EUSES
}

\section{Earthquakes in Ohio and Vicinity 1776-2007}

\section{8}

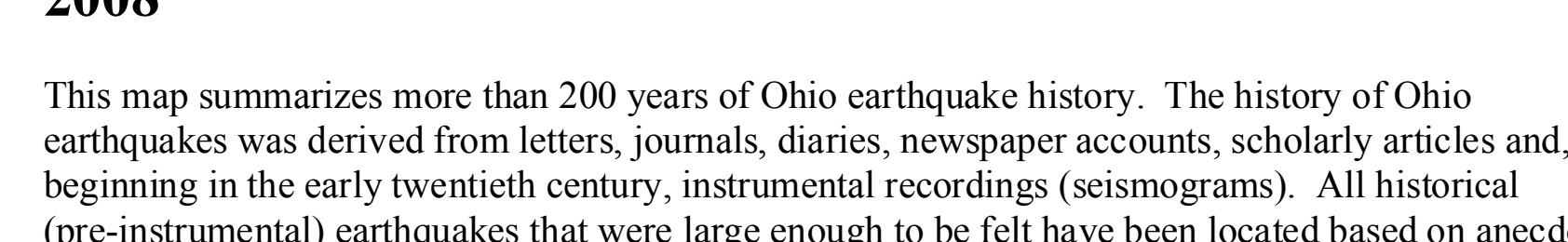

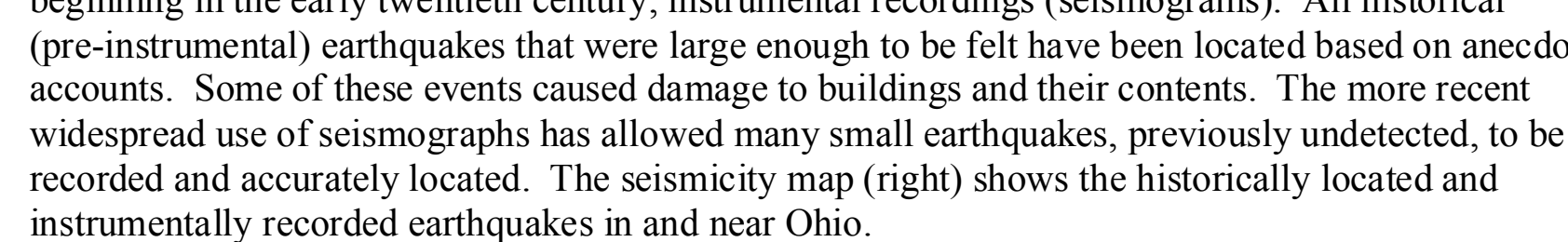

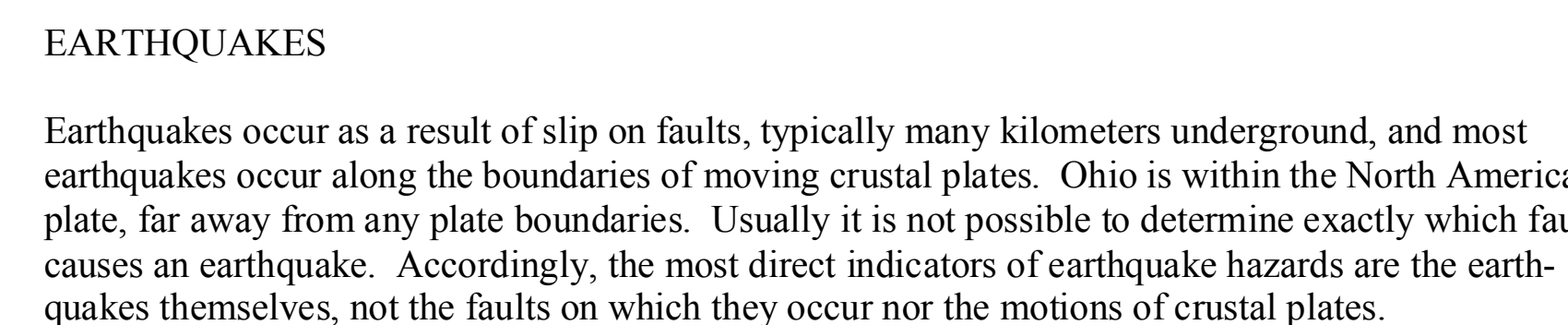

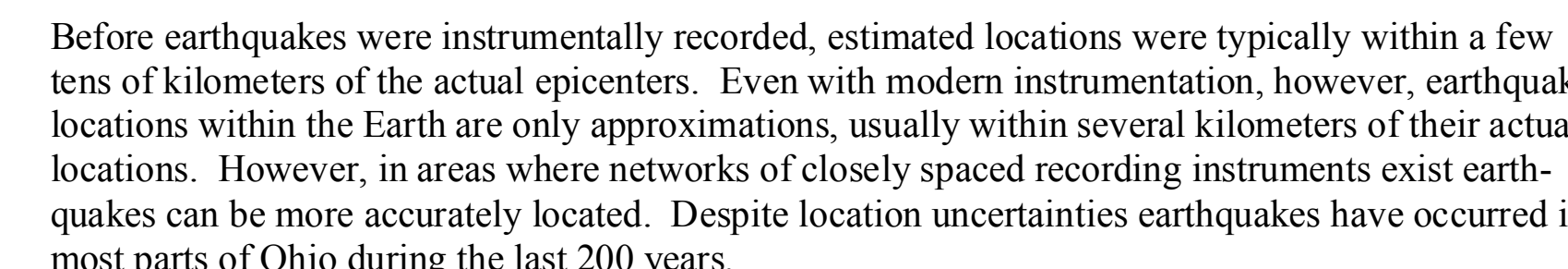

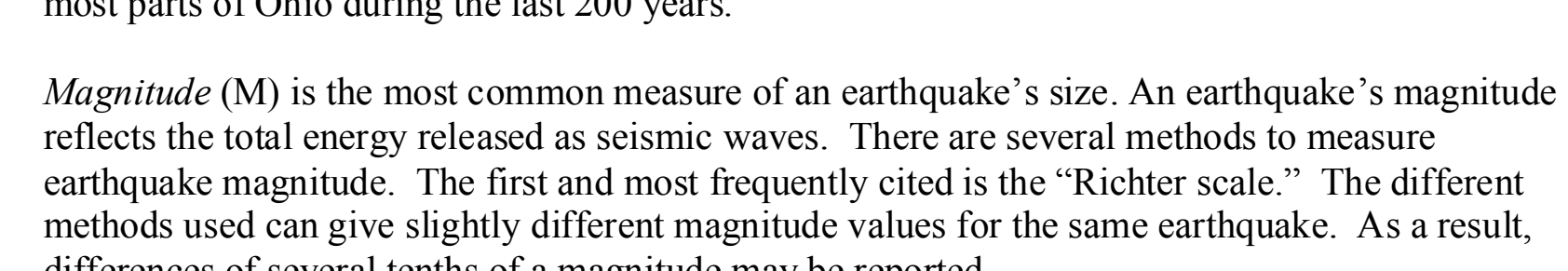

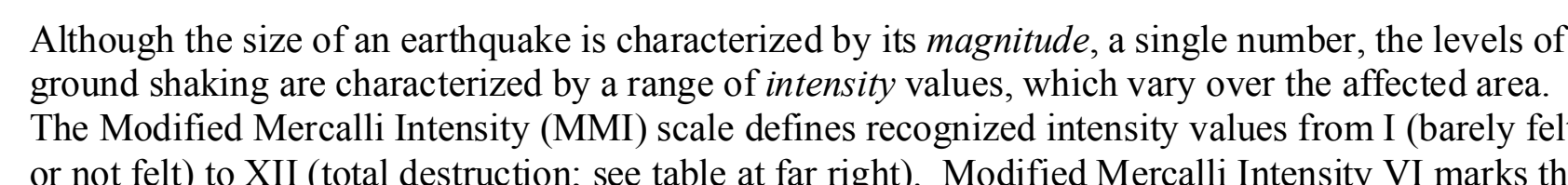

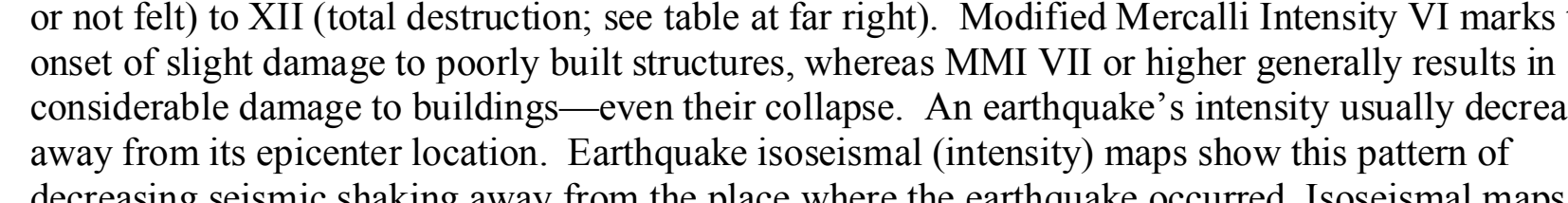

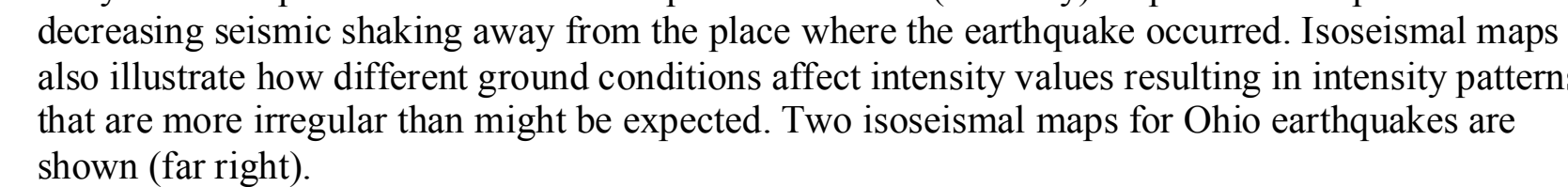

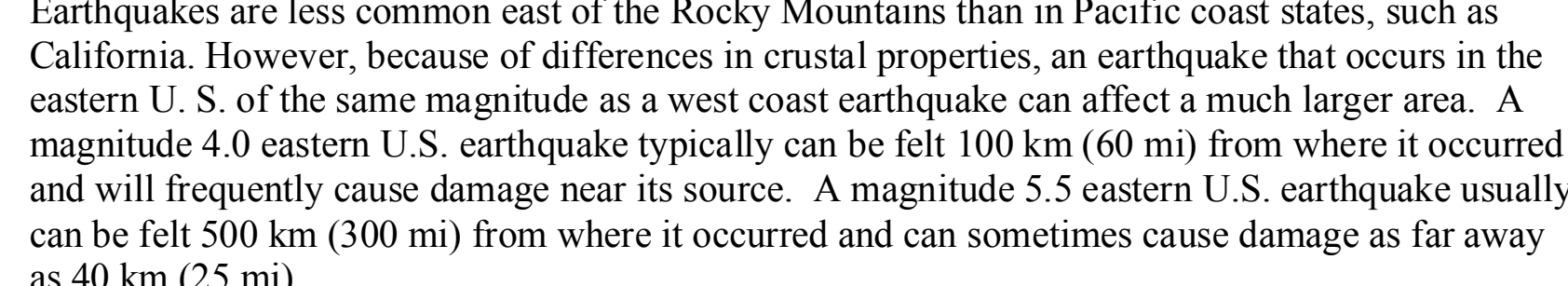

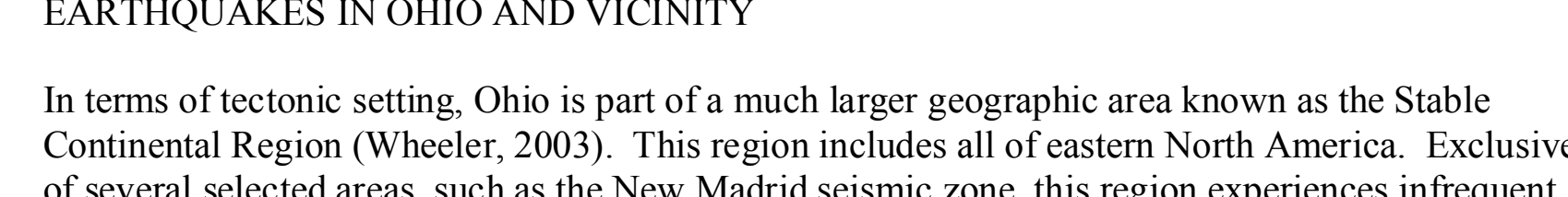

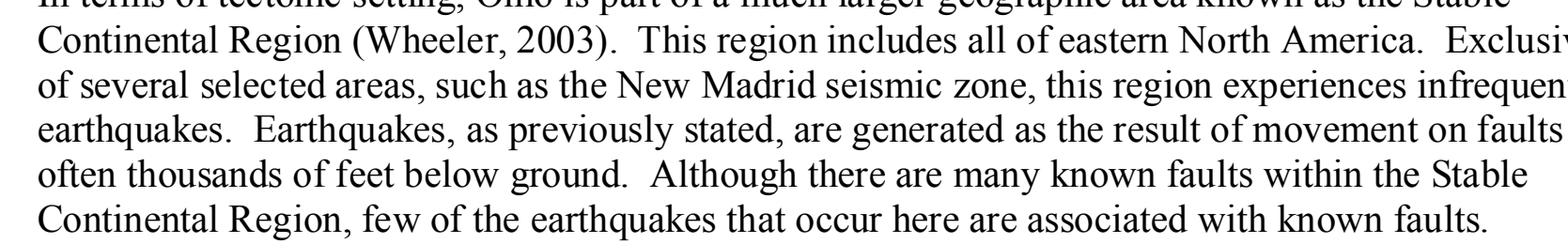

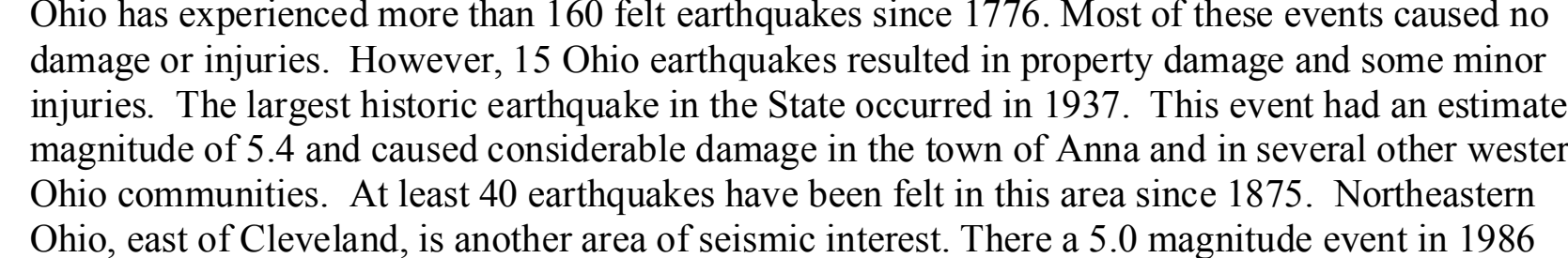

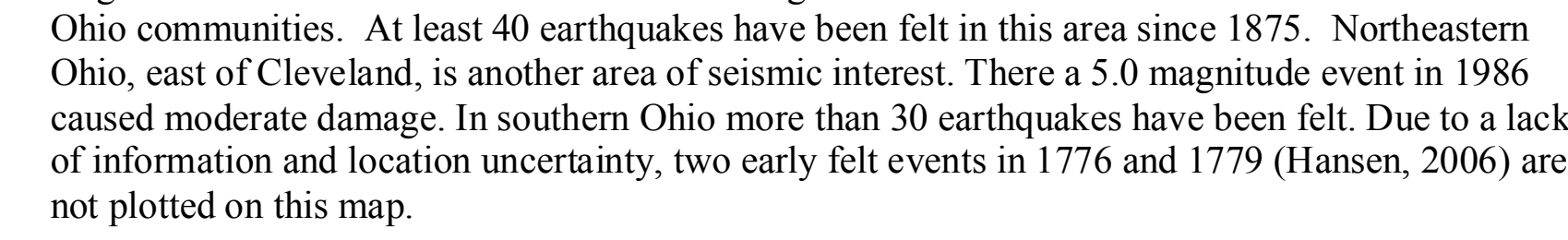

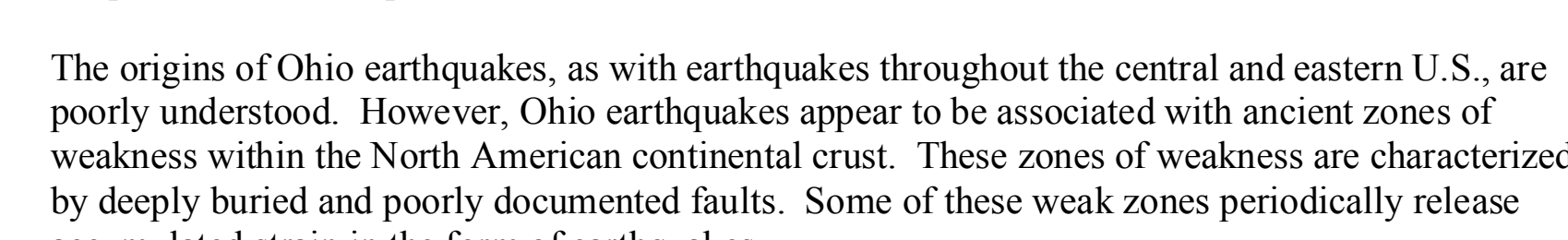

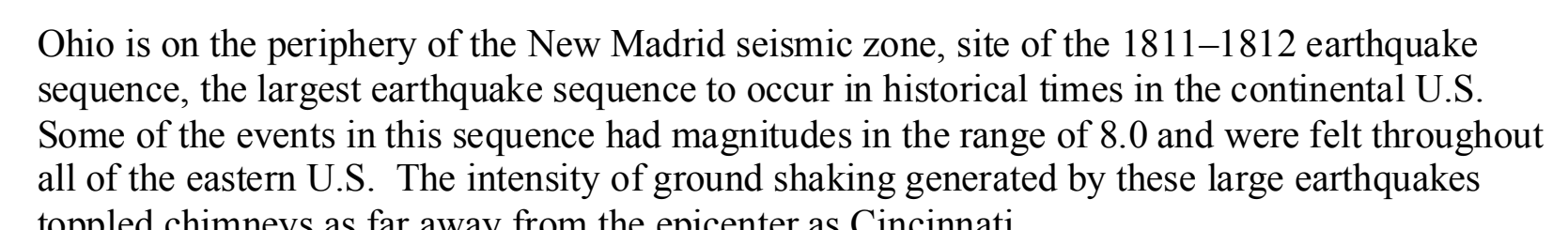

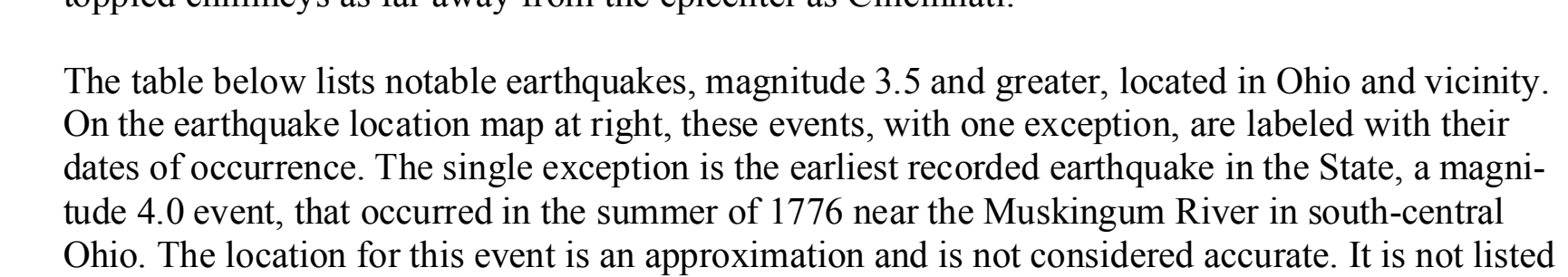
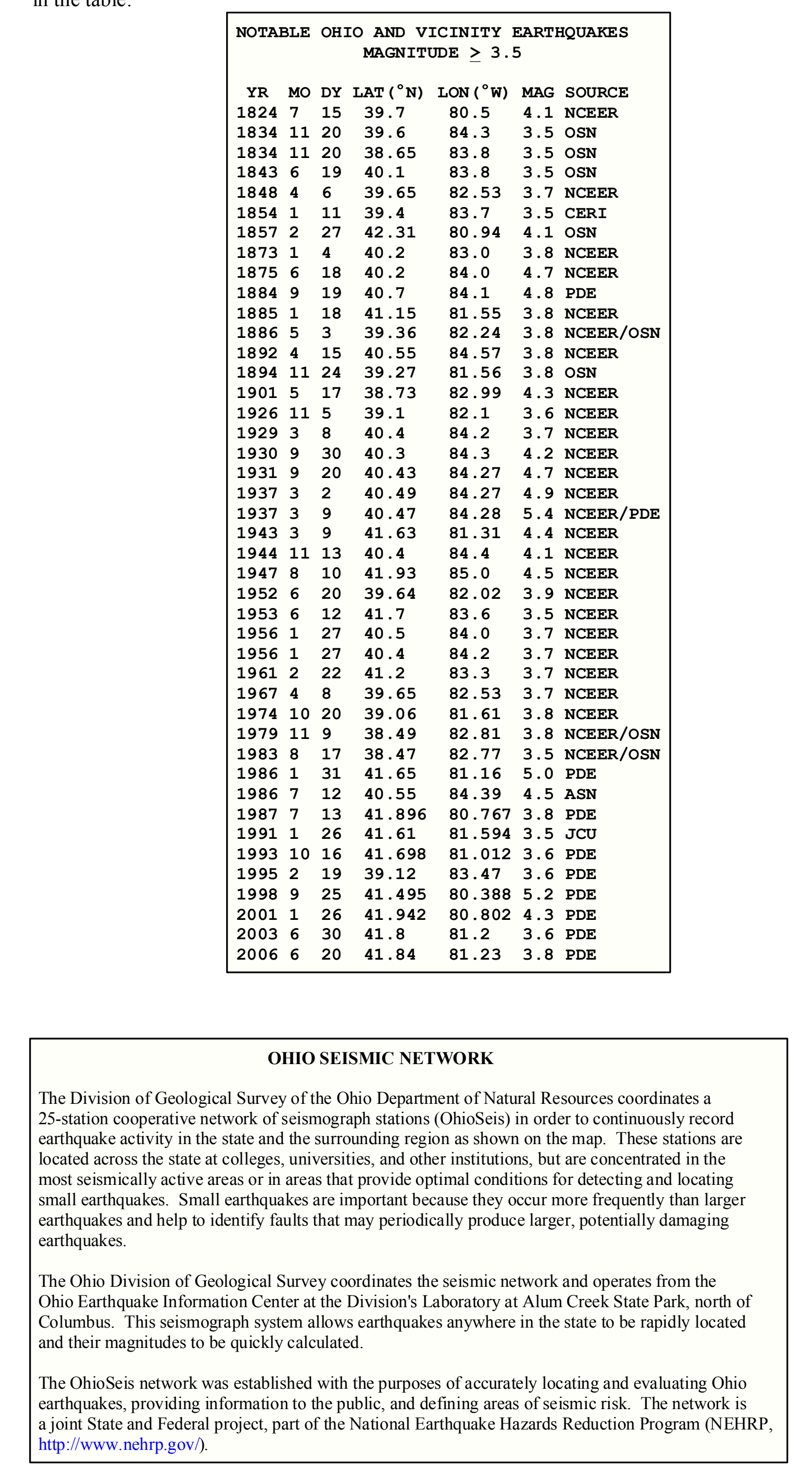

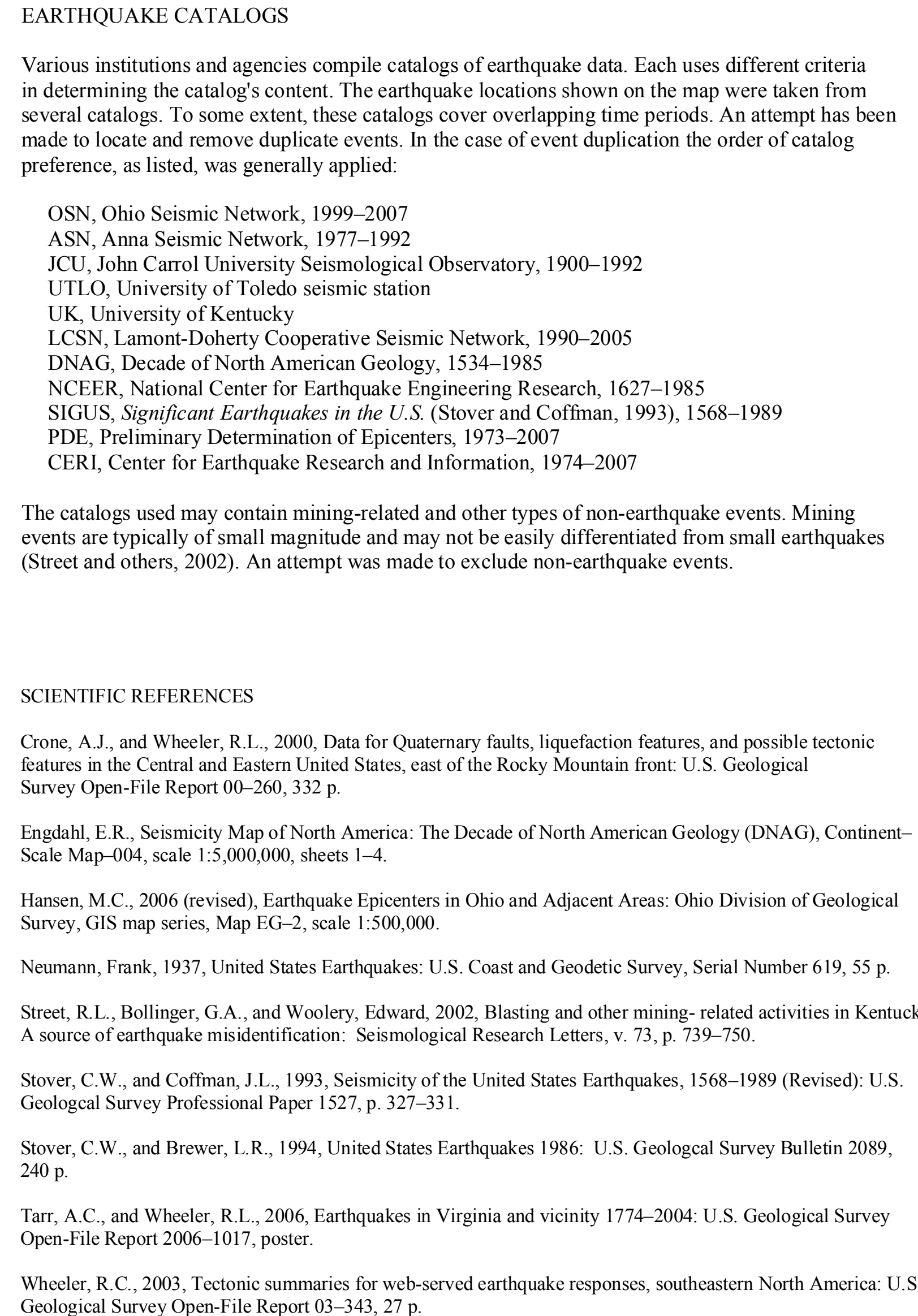

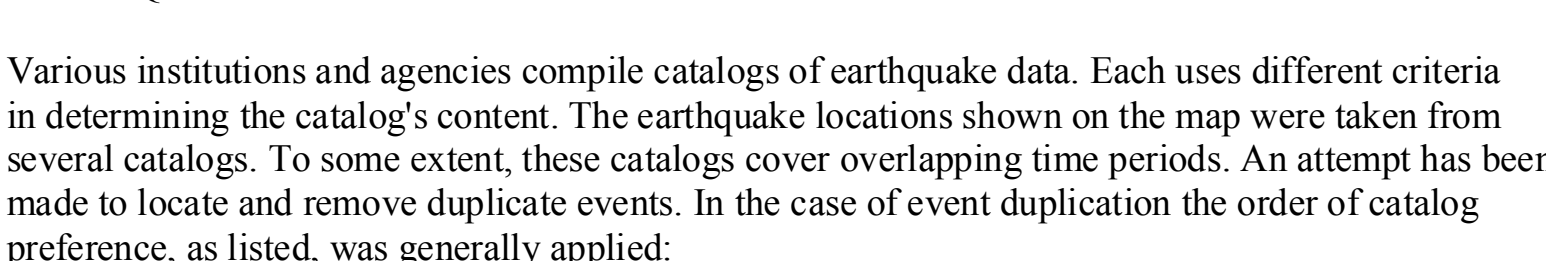

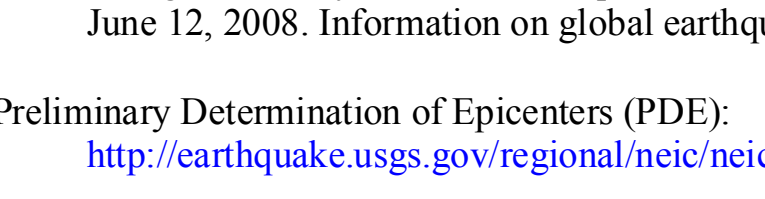

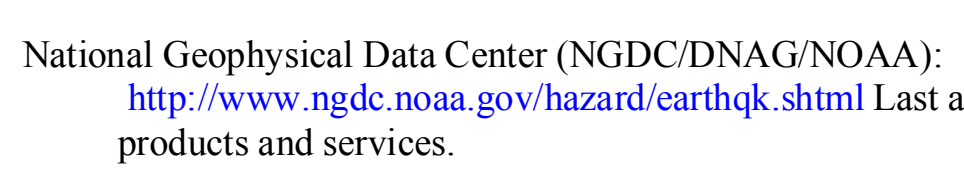

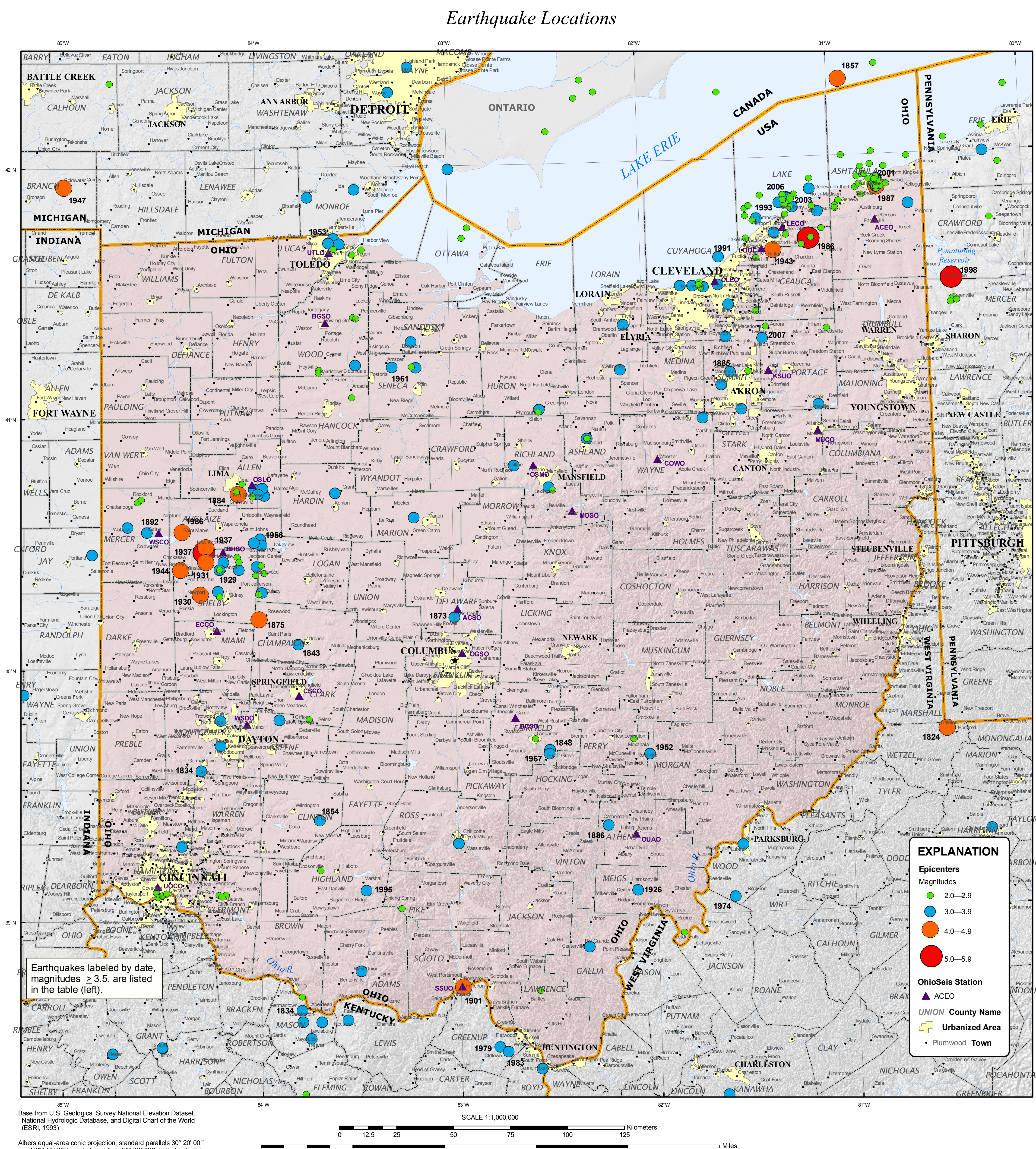

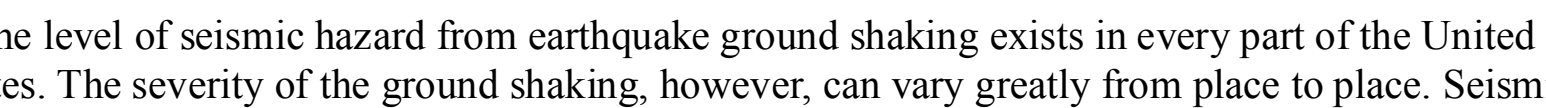

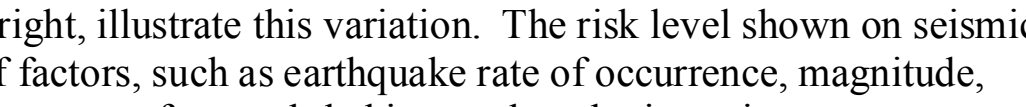

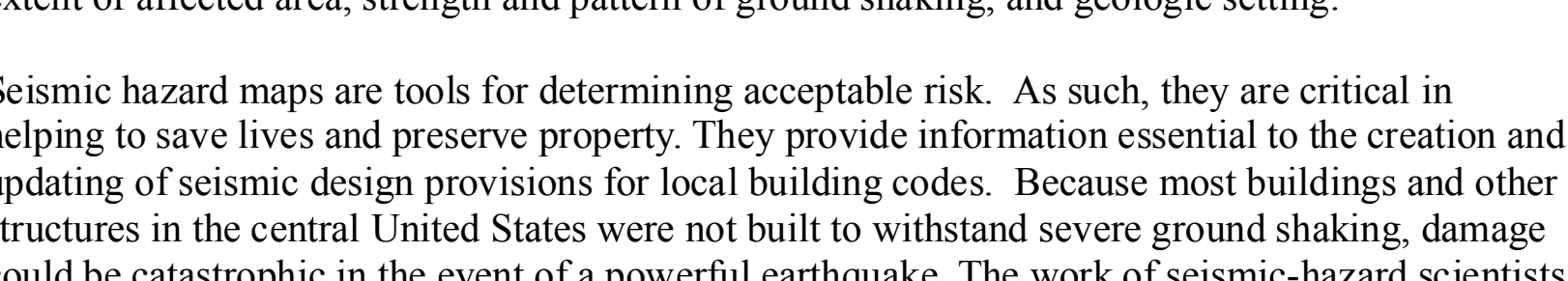

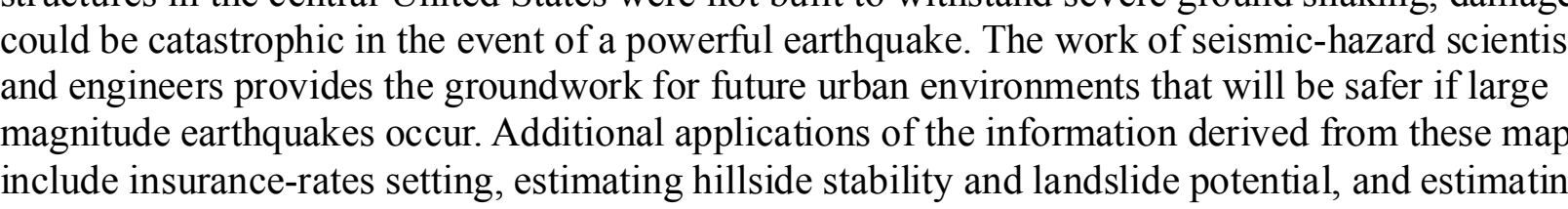

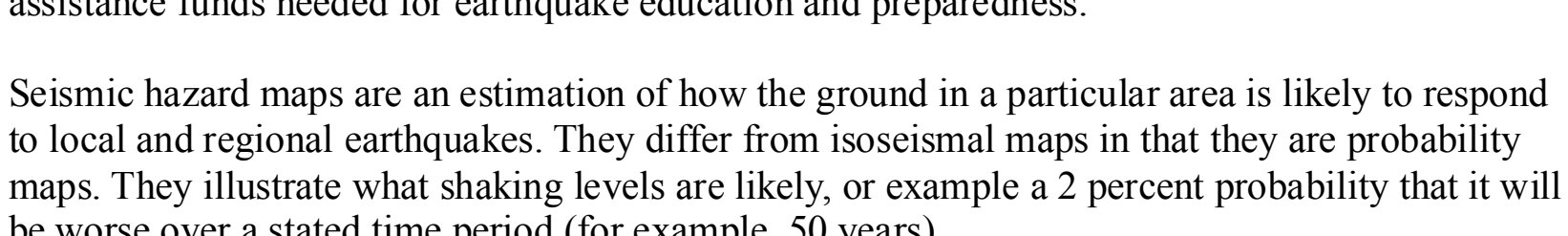

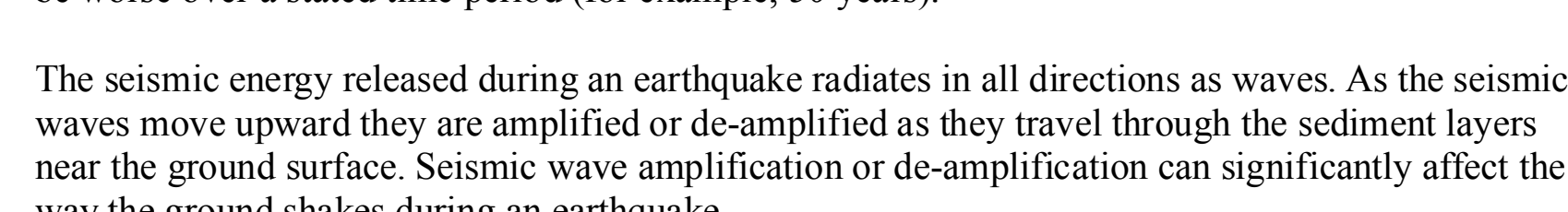

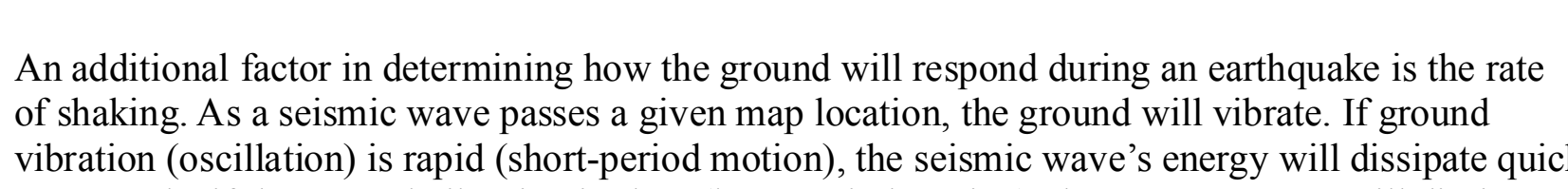

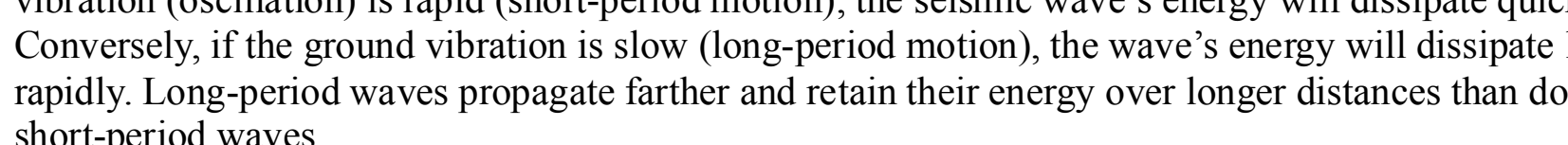

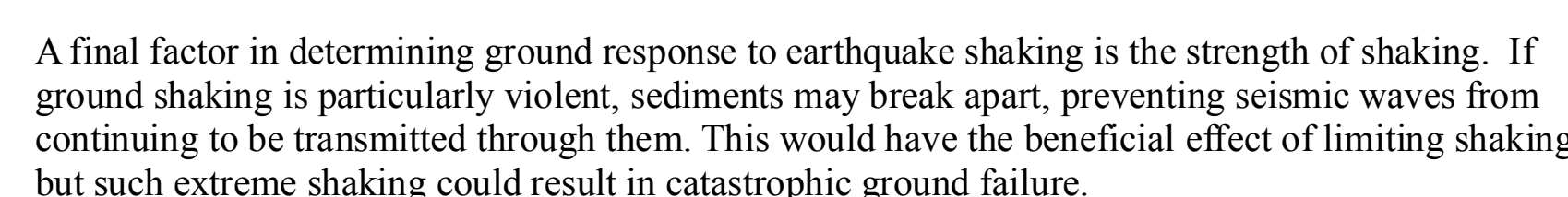

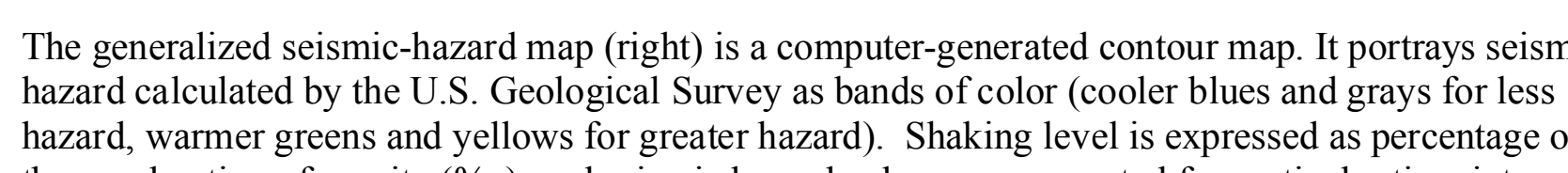

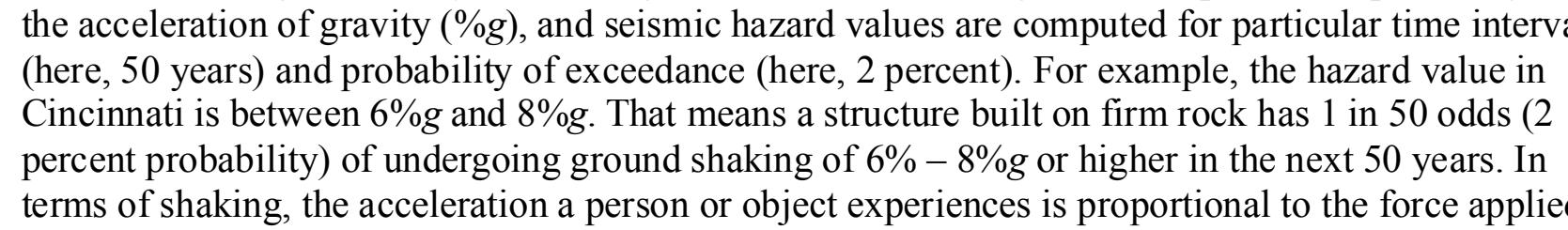

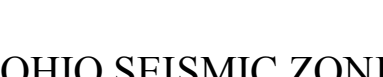

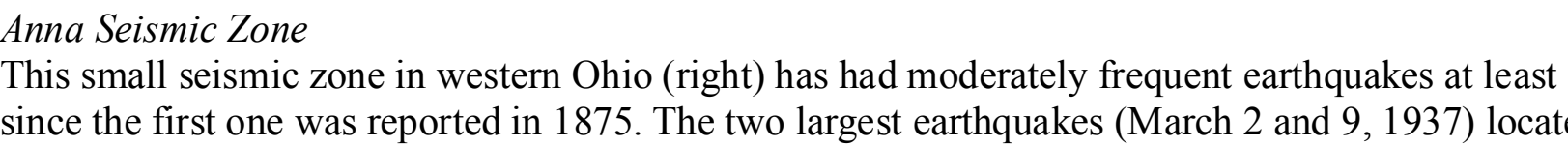

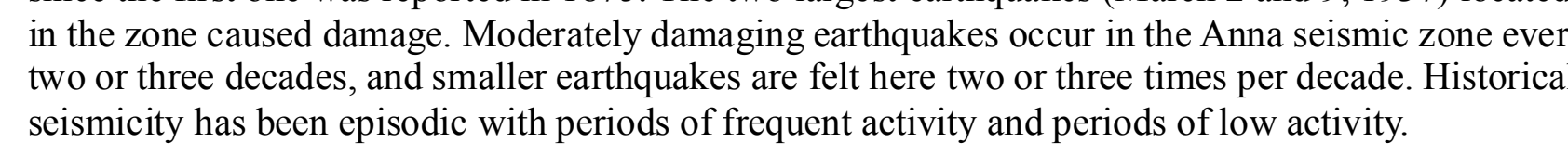

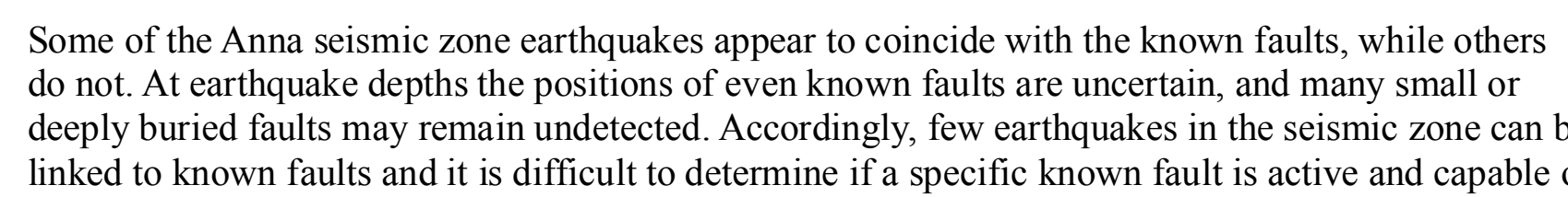

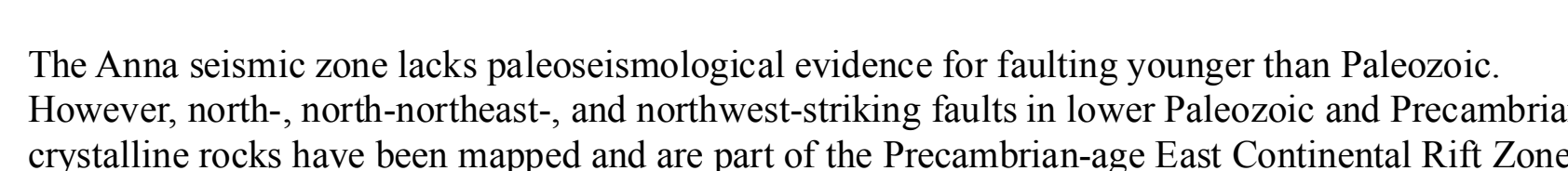
ceverat housand year

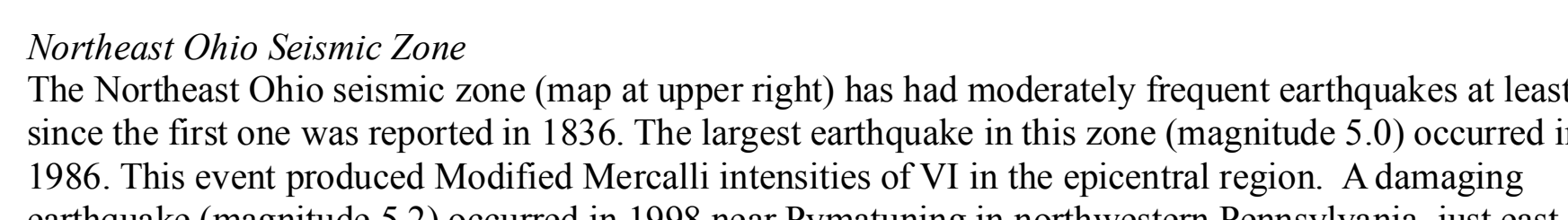

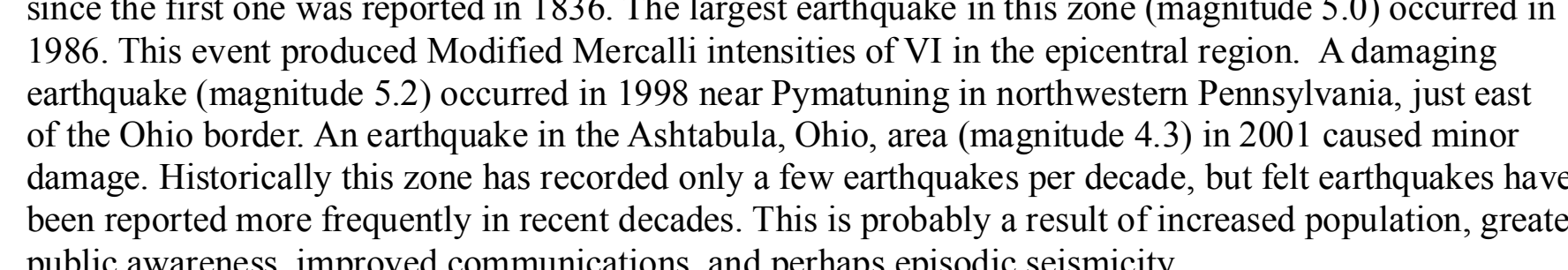

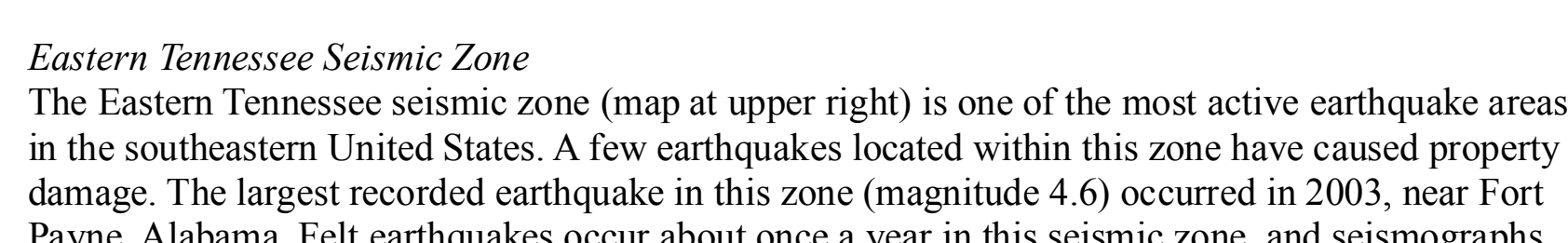

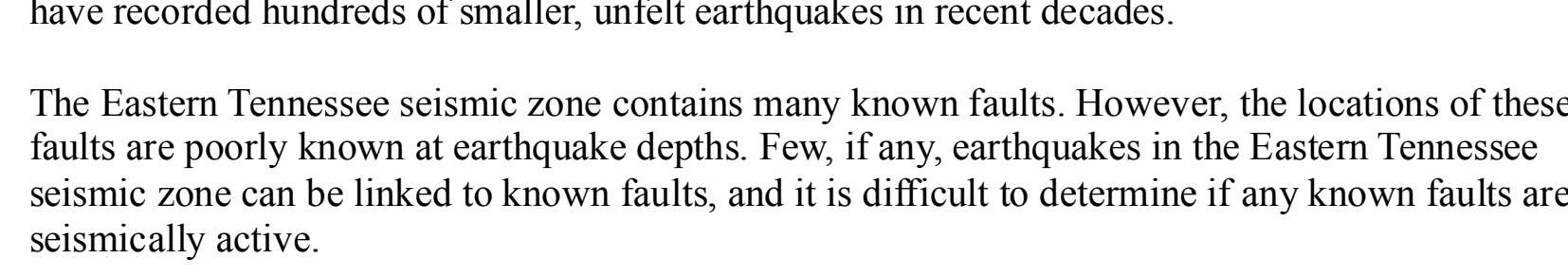

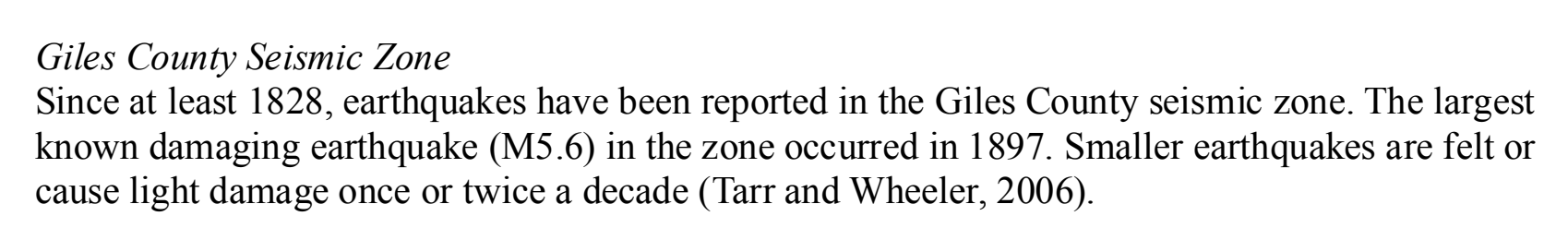

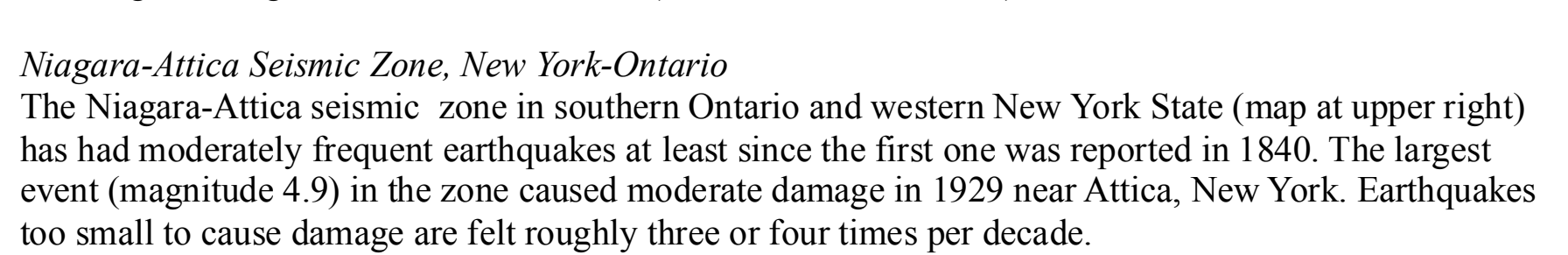

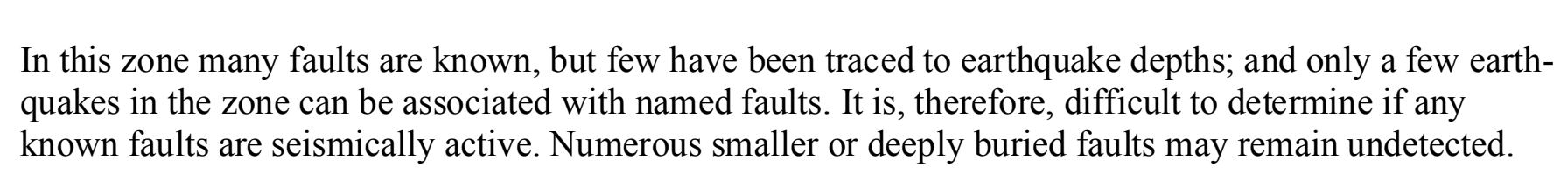

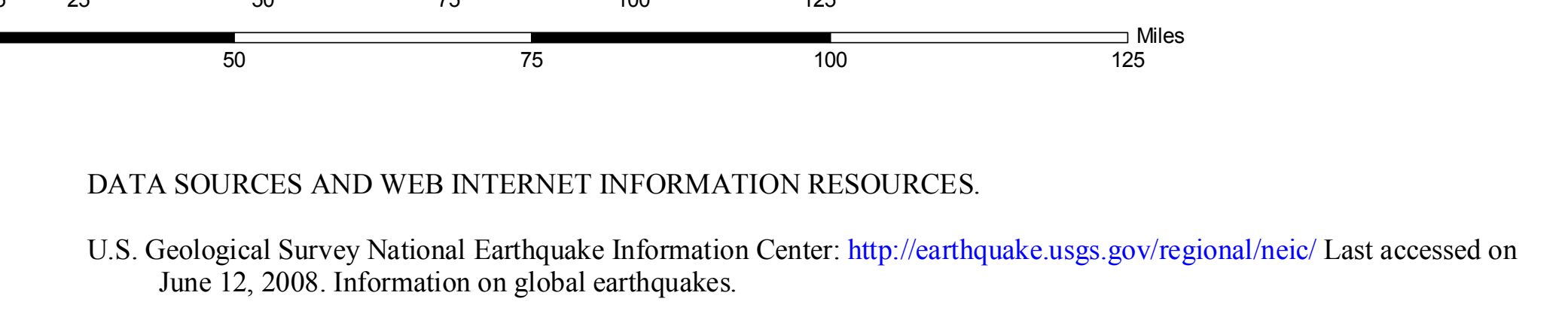

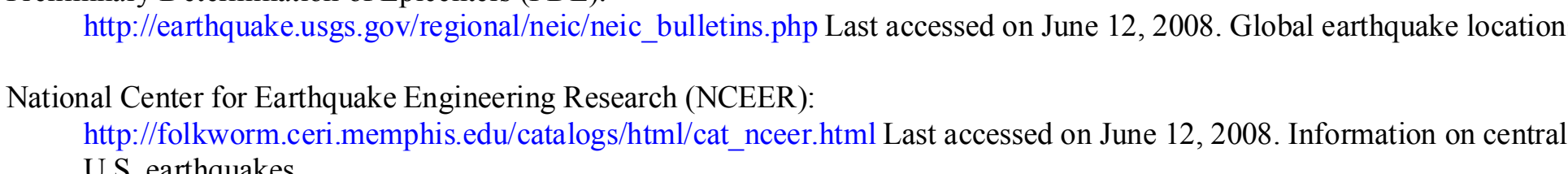

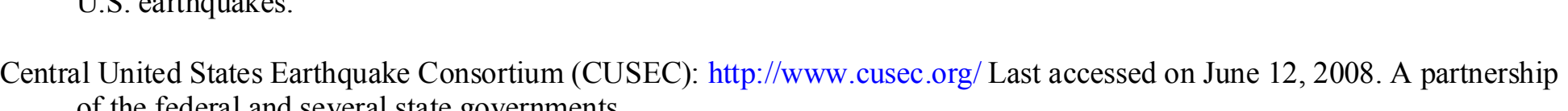

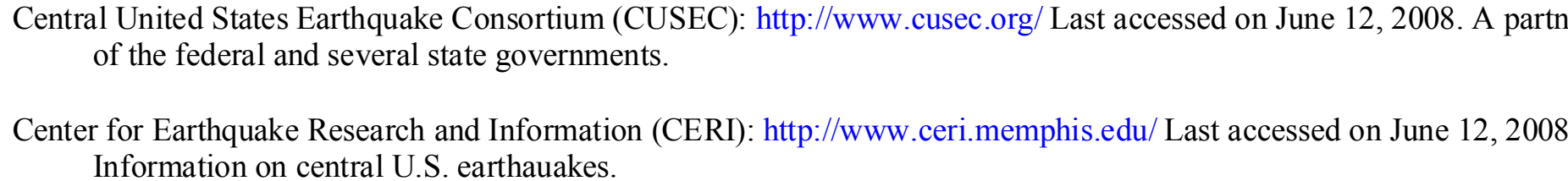

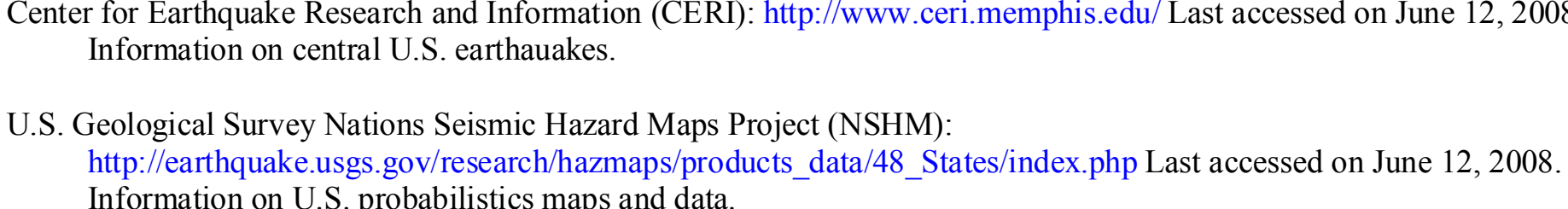

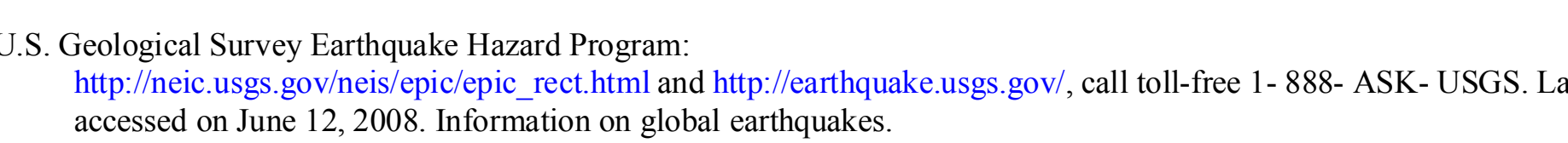

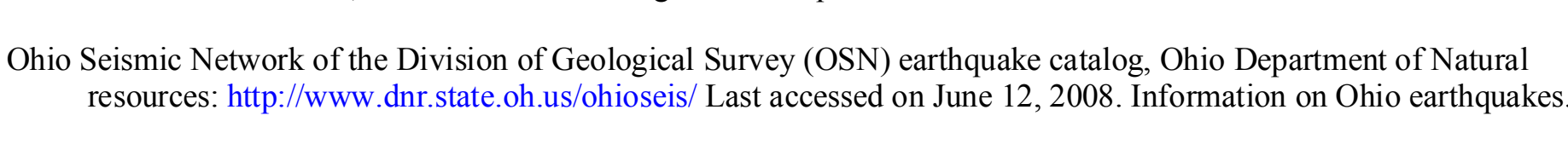

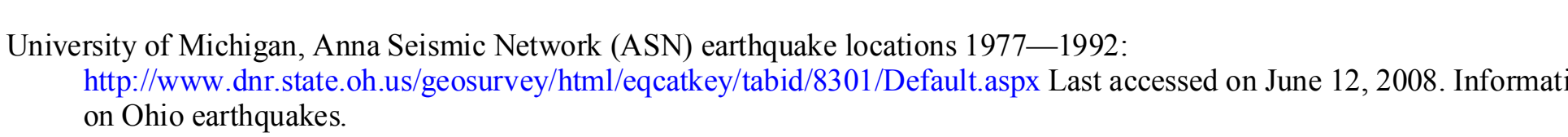

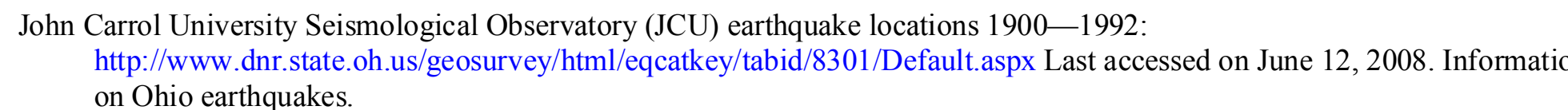

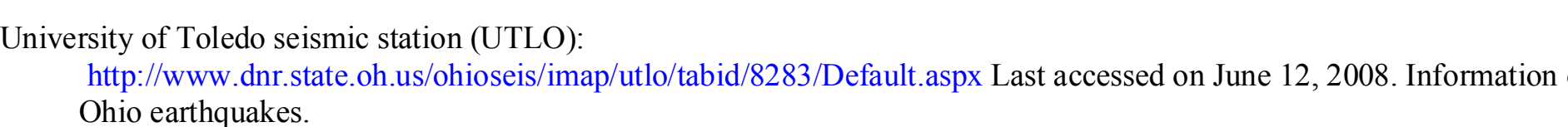

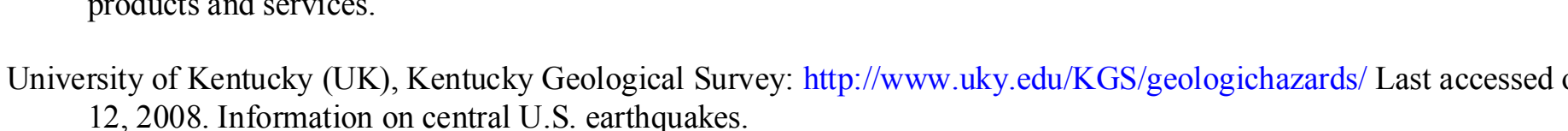

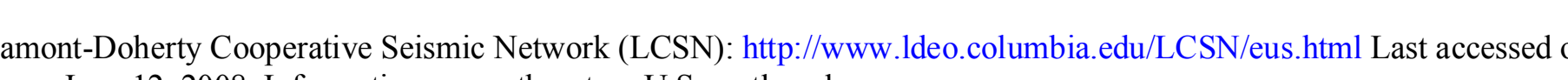

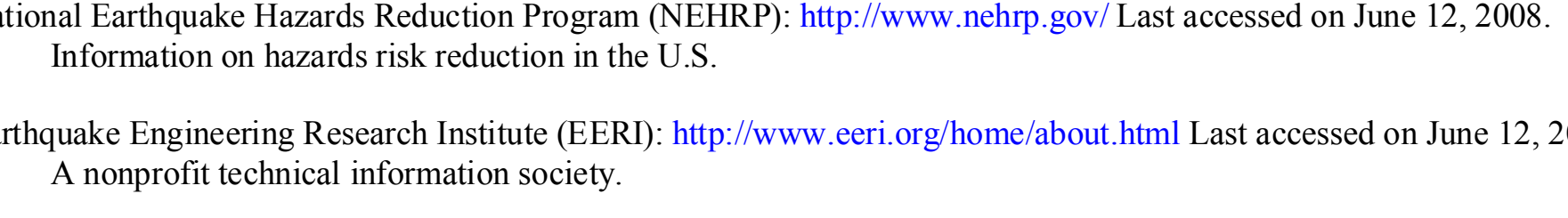

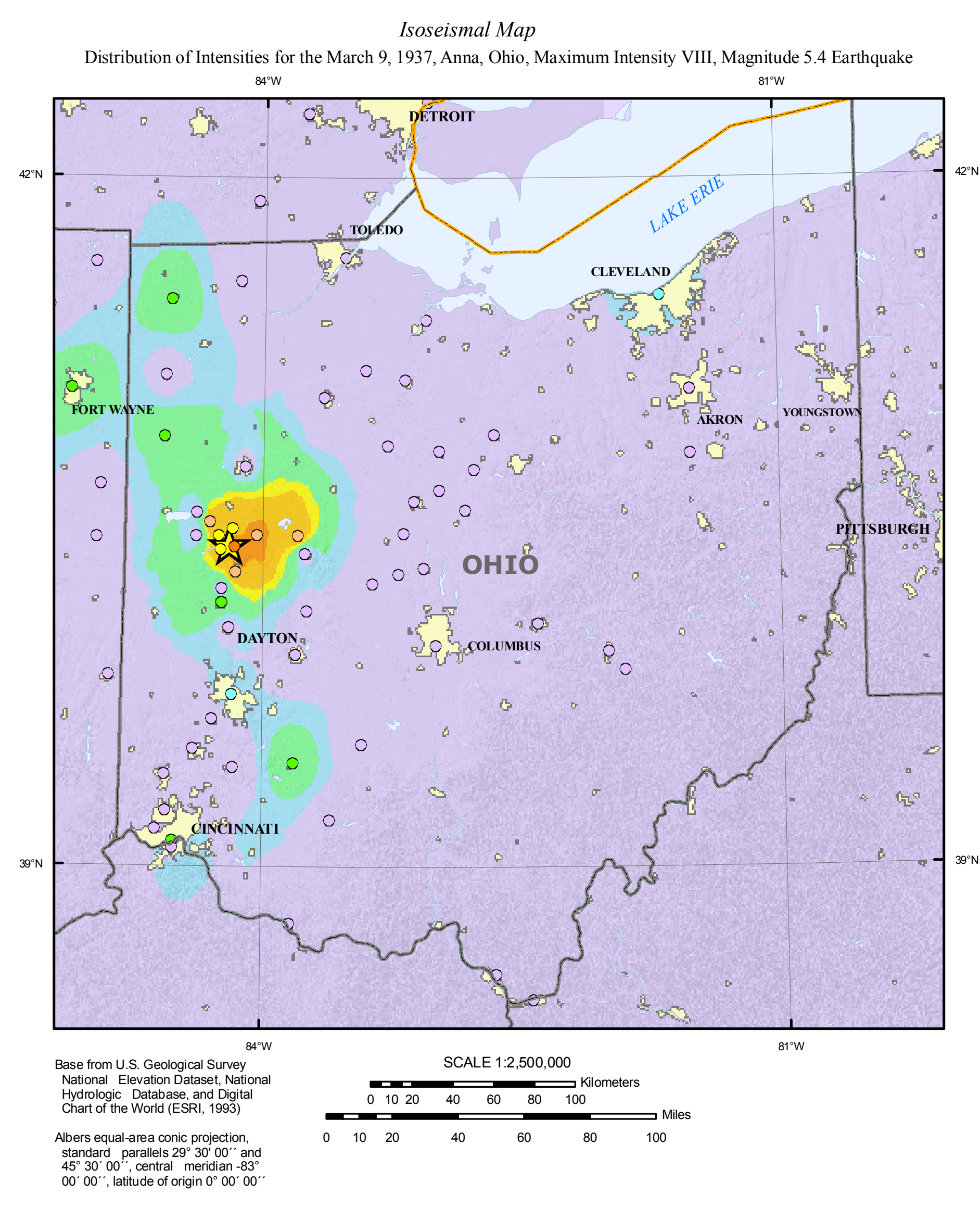

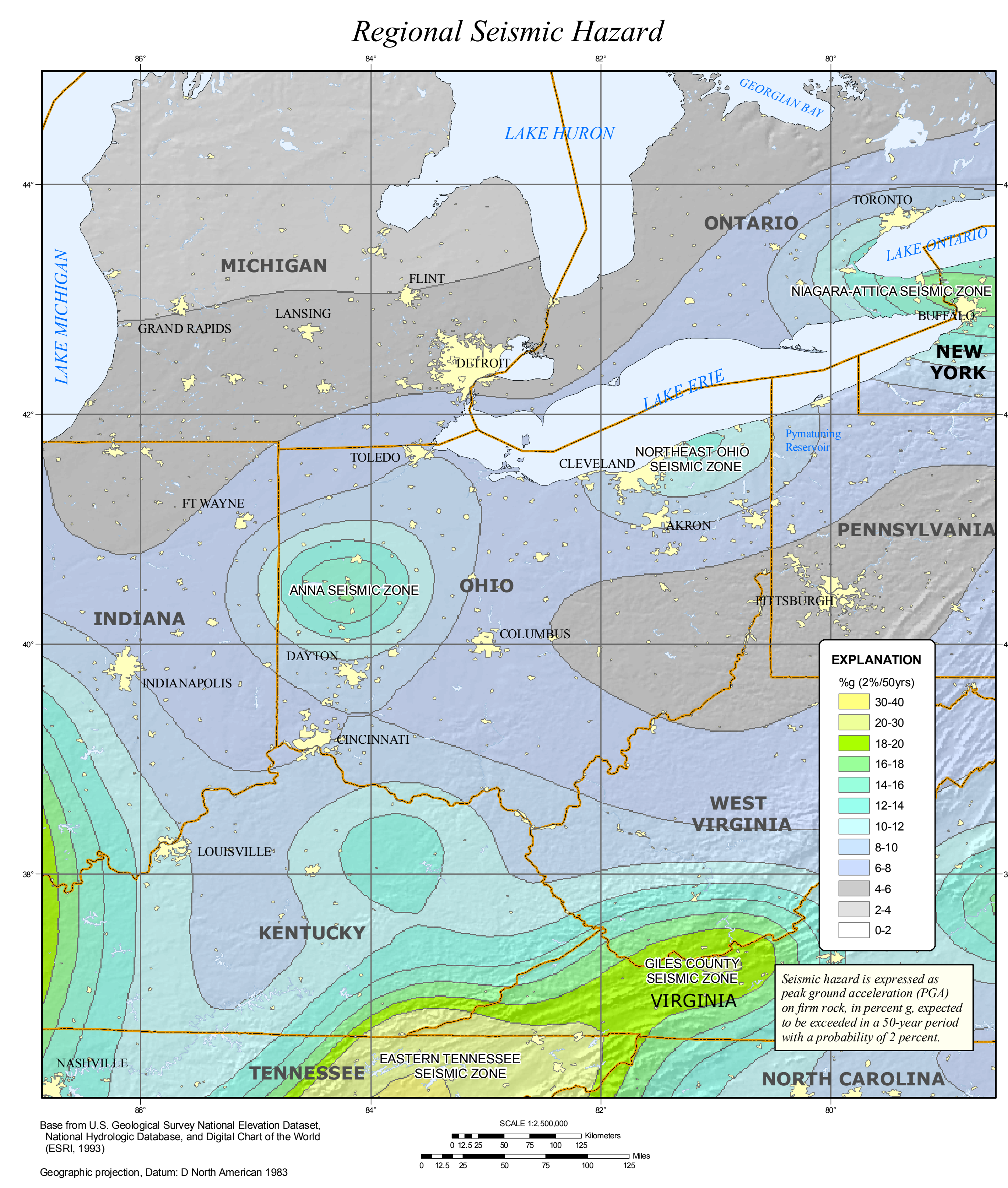
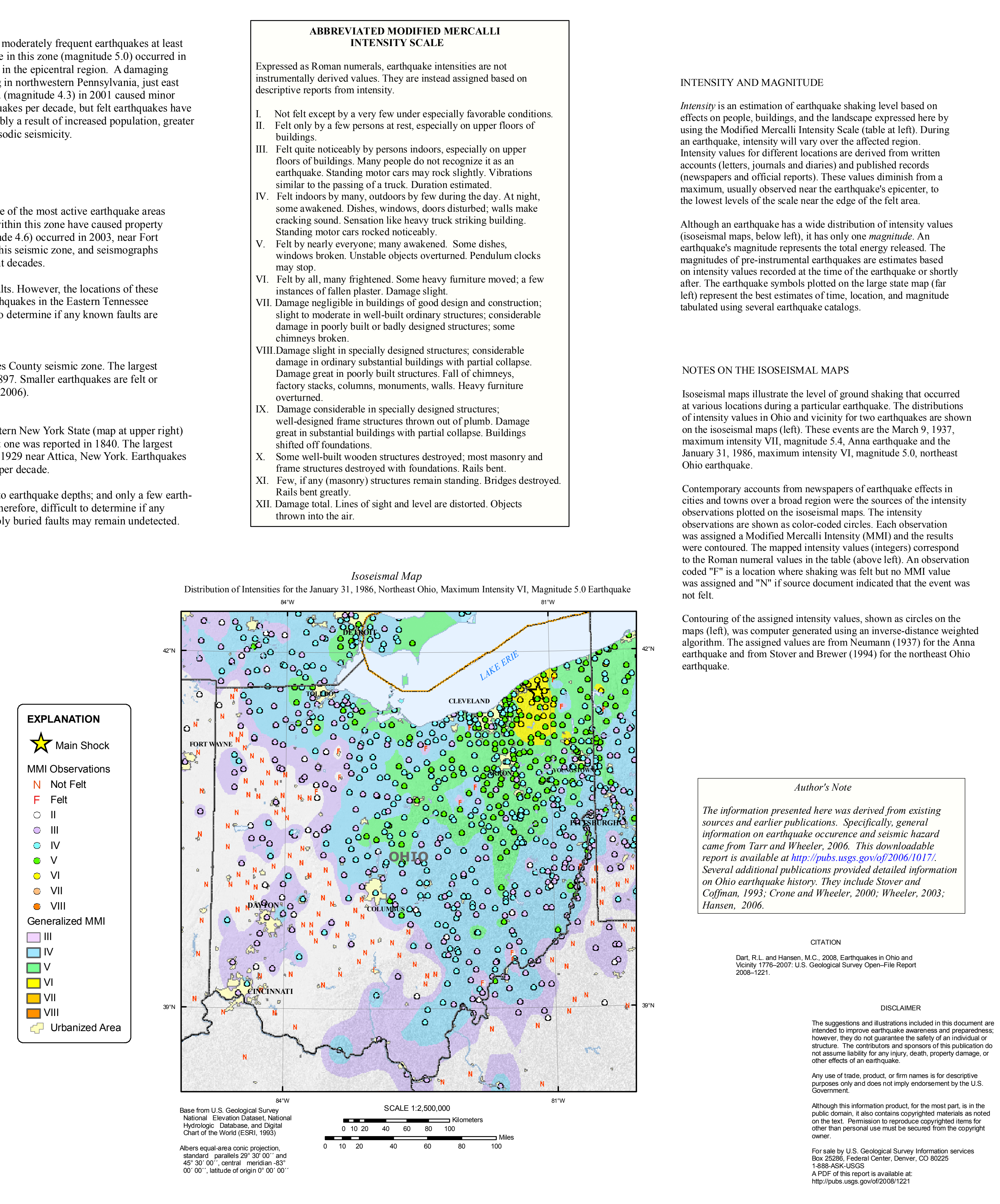